\title{
Identification of carbapenemase genes in Serratia spp
}

\author{
Peceu Magyve Ragagnin De Oliveira ${ }^{*}$, Wirlaine Glauce Maciel', José Lourenço Dos Santos Cunha E Silva', \\ Kesia Esther Da Silva², Maisa Estopa Correa², Nathalie Gaebler Vasconcelos ${ }^{2}$, Flávia Patussi Correia Sacchi \\ Mariana Trinidad Ribeiro Da Costa Garcia Croda², Fábio Juliano Negrão², Júlio Henrique Rosa Croda², \\ Simone Simionatto ${ }^{1}$
}

From 5th Congress of the Brazilian Biotechnology Society (SBBIOTEC)

Florianópolis, Brazil. 10-14 November 2013

\section{Background}

Reports of nosocomial infection due to carbapenem resistant Serratia spp. have become significantly more common. This resistance may be due to production of distinct carbapenemases, such as KPC $[1,2]$. This enzyme, initially described in Klebsiella pneumoniae isolates, has also been detected among other organisms, such as Serratia marcescens, emphasizing the global risk of interspecies spread of resistance genes [2,3]. The aim of this study was to identify carbapenemase genes in Serratia spp. Isolated of nosocomial infection.

\section{Methods}

The samples were collected during May/2012 to May/ 2013. The strains were recovered from urinary tract, tracheal aspirate and blood culture from patients hospitalized Dourados/MS hospital. The identification of Serratia spp. and the sensitivity test was carried out using a Vitek (BioMérieux) automated system. All strains with reduced susceptibility to imipenem or meropenem were screened for carbapenemase production by the modified Hodge test as recommended by the Clinical and Laboratory Standards Institute [4]. The presence of KPC coding gene was assessed by PCR as described by Cuzon et al. (2010) [5].

\section{Results and conclusions}

From May/2012 to May/2013, fifty strains of Serratia spp. were isolated. The wards that had the highest incidence of Serratia spp. were the intensive care units (ICUs).

${ }^{1}$ Faculty of Biological and Environmental Sciences, 32279804-970, Federal University of Grande Dourados, Dourados, MS, Brazil

Full list of author information is available at the end of the article
The strains identified as producing carbapenemases were evaluated by PCR using primers specific for $b l a_{K P C}$ gene. Fourteen Serratia spp. strains were positive in PCR. This work describes the first report of KPC gene in Serratia spp. isolates in Mato Grosso do Sul, Brazil and confirm the high level of resistance of Serratia spp. against carbapenemics. The clinical importance of detecting carbapenemases producing Serratia spp. is to contribute to hospital infection control, reducing the spread of multidrug-resistant microorganisms and providing results that help in choosing the most appropriate antimicrobial, prolonging patient survival.

\section{Acknowledgements}

This work was supported by the Foundation Support the Development of Education, Science and Technology of the State of Mato Grosso do Sul (FUNDECT, 05/2011 and 04/2012).

\section{Authors' details}

${ }^{1}$ Faculty of Biological and Environmental Sciences, 32279804-970, Federal University of Grande Dourados, Dourados, MS, Brazil. ${ }^{2}$ Faculty of Health Sciences, 79800-000, Federal University of Grande Dourados, Dourados, MS, Brazil.

Published: 1 October 2014

\section{References}

1. Mahlen SD: Serratia Infections: from Military Experiments to Current Practice. Clinical Microbiology Reviews 2011, 24(4):755-791.

2. Queenan AM, Bush K: Carbapenemases: the versatile beta-lactamases. Clinical Microbiology and Infection 2007, 20(3):440-458.

3. Cohen Stuart Leverstein-Van Hall: Dutch Working Party on the Detection of Highly Resistant Microorganisms: Guideline for phenotypic screening and confirmation of carbapenemase in Enterobacteriaceae. Int $J$ Antimicrob Agents 2010, 36(3):205-210.

4. Clinical and Laboratory Standards Institute: Performance standards for antimicrobial susceptibility testing. CLSI document M100-S23. Clinical and Laboratory Standards Institute, Wayne, PA.; 2013. 
5. Cuzon G, Nass T, Truong H, Villegas MV, Wisell KT, Carmeli Y, Gales AC, Navon-Venezia S, Quinn JP, Nordmann P: Worldwide diversity of Klebsiella pneumoniae that produces $\beta$-lactamase blaKPC-2 gene. Emerging Infectious Disease 2010, 16(9):1349-1356.

doi:10.1186/1753-6561-8-S4-P39

Cite this article as: De Oliveira et al:: Identification of carbapenemase genes in Serratia spp. BMC Proceedings 2014 8(Suppl 4):P39.

Submit your next manuscript to BioMed Central and take full advantage of:

- Convenient online submission

- Thorough peer review

- No space constraints or color figure charges

- Immediate publication on acceptance

- Inclusion in PubMed, CAS, Scopus and Google Scholar

- Research which is freely available for redistribution

Submit your manuscript at www.biomedcentral.com/submit 